Eos, Vol. 95, No. 20, 20 May 2014

\title{
MEETING
}

\section{Drilling to Resolve the Evolution of the Corinth Rift}

\section{IODP Ocean Drilling Within the Corinth Rift, Greece; Athens, Greece, 11-14 February 2014}

\section{PAGE 170}

The initiation and evolution of continental rifting, ultimately leading to rifted margin and ocean basin formation, are major unanswered questions in solid Earth-plate tectonics. Many previous insights have come from mature rifted margins where activity has ceased or from computer models. The Gulf of Corinth Rift in central Greece presents an ideal laboratory for the study of young, highly active rifting that complements other rift zones (e.g., the East African and Gulf of California rifts). Exposure and preservation of syn-rift stratigraphy, high rates of extension, and an existing network of offshore seismic data offer a unique opportunity to constrain the rift history and basin development at exceptionally high resolution in the Gulf of Corinth.

An international collaborative project, launched in 2011, is integrating all marine geophysical data sets to generate a highresolution, high-precision fault network and stratigraphic framework of the modern rift axis combined with an equivalent onshore framework. The missing piece of the jigsaw for the Corinth Rift tectonic framework is offshore drilling at key locations to provide a chronology for the entire offshore basin, incidentally creating a high-resolution late Pliocene-Quaternary paleoclimatic and paleoenvironmental record.

To support preparation of a proposal to the International Ocean Discovery Program (IODP), a workshop was held on 11-14 February 2014 in Athens, Greece. The workshop was financially supported by the Natural Environment Research Council, UK, the European Consortium for Ocean Research Drilling/ International Continental Scientific Drilling Program (ECORD/ICDP), MagellanPlus Workshop Series Program, and the Hellenic Centre for Marine Research, Greece. A 2-day meeting, attended by 36 participants from six countries, including students and early-career researchers, was followed by a 1-day field trip to the rift zone and 1 day of proposal preparation by a subset of participants.

Presentations included keynotes on key global rift questions and modeling techniques of rift processes and on current knowledge of Corinth rift chronostratigraphy, fault basin evolution, sediment flux history and modeling potential, seismology, deep crustal structure, and the potential application of drilling to regional hazard assessment. The latest results of the marine data integration project were discussed, alongside regional complementary research projects. A session was devoted to discussion of ocean drilling core analysis techniques to establish a high-fidelity chronological and environmental record. An ECORD representative provided critical information on Mission Specific Platform methodologies and constraints for drilling in this environment.

Workshop discussions identified potential drill site locations framed around the temporal and spatial resolution of processes that could be generated from the Corinth Rift, probably unparalleled worldwide, and generated the following primary scientific objectives: determine the evolution of a rift-controlled drainage system in time and space, including the relative contributions of tectonics and climate; constrain the distribution of tectonic strain in time and space and growth history of a rift-scale normal fault network; and establish the time scale of rift segment initiation and maintenance.

The meeting was extremely productive with strong endorsement of the Corinth Rift system as a key target to address global rift problems. As a result of the workshop, a proposal will be submitted to IODP on 1 October 2014 to propose drilling within the Corinth Rift system.

—LISA MCNEILL, University of Southampton, UK; email: lcmn@noc.soton.ac.uk; DIMITRIS SAKELLARIOU, Hellenic Centre for Marine Research, Anavyssos, Greece; and CASEY NIXON, University of Southampton, UK 